\title{
非晶質リン酸カルシウムの結晶化による新相の生成と性質
}

\author{
遠山岳史・安江 任・荒井康夫 \\ 日本大学理工学部工業化学科, 101 東京都千代田区神田駿河台 1-8
}

\section{Formation of a New Phase by Crystallizing Amorphous Calcium Phosphate and Its Property}

\author{
Takeshi TOYAMA, Tamotsu YASUE and Yasuo ARAI \\ Department of Industrial Chemistry, Faculty of Science and Engineering, Nihon University, 1-8, Kanda-Surugadai, Chiyoda-ku, Tokyo
}

\begin{abstract}
Amorphous calcium phosphate (ACP), which generally forms as an unstable precursor during the initial stage of hydroxyapatite (HAp) synthesis, was synthesized by rapid dropwise addition of aqueous ammonia into calcium dihydrogenphosphate monohydrate (MCP) solution. ACP was crystallized easily to various calcium phosphates such as dicalcium phosphate dihydrate (DCPD), octacalcium phosphate (OCP) and HAp by dipping ACP ( $\mathrm{Ca} / \mathrm{P}$ atomic ratio 1.25-1.55) in various solutions. The present work was undertaken in order to elucidate the crystallizing conditions, composition and crystallographic data of a new phase formed by crystallizing ACP. The new phase was characterized by means of X-ray diffraction, thermal analysis (TGDTA), infrared spectroscopy and scanning electron microscopy. The new phase was formed only by dipping $\mathrm{ACP}$ with a $\mathrm{Ca} / \mathrm{P}$ atomic ratio above 1.40 in aqueous solution at $0^{\circ} \mathrm{C}$ for $24 \mathrm{~h}$. The results of chemical analysis and thermal analysis (TG-DTA) determined the chemical formula of the new phase to be $\mathrm{Ca}_{3}\left(\mathrm{PO}_{4}\right)_{2} \cdot 8 \mathrm{H}_{2} \mathrm{O}$. Powder X-ray diffraction data did not correspond to those of already known calcium phosphates. Also, it was proved that crystallographic data of the new phase belongs to the monoclinic system with $a=1.312 \mathrm{~nm}$, $b=1.111 \mathrm{~nm}, c=1.264 \mathrm{~nm}, \beta=109.0^{\circ}$. Its crystal shape was plate-like $4-6 \mu \mathrm{m}$ across.
\end{abstract}

[Received December 27, 1996; Accepted August 7, 1997]

Key-words : Amorphous calcium phosphate, Tricalcium phosphate octahydrate, New phase, Crystallographic data

1. 緒言

非晶質リン酸カルシウム $\left(\mathrm{ACP}, \mathrm{Ca}_{3}\left(\mathrm{PO}_{4}\right)_{2} \cdot n \mathrm{H}_{2} \mathrm{O}\right)$ は生体内 での硬組織の主成分である水酸アパタイト $\left(\mathrm{HAp}, \mathrm{Ca}_{10}\left(\mathrm{PO}_{4}\right)_{6}\right.$ $\left.(\mathrm{OH})_{2}\right)$ の前駆物質であることはよく知られている. ACP は, 塩化カルシウムなどのカルシウム塩とリン酸塩を混合すること により幅広い範囲の $\mathrm{Ca} / \mathrm{P}$ 原子比のものを得ることができる.

著者らは, 非晶質カルシウム化合物に関する一連の研究を 行っており1) 14), 非晶質リン酸カルシウムに関しては, これ までにリン酸二水素カルシウム一水和物 $\left(\mathrm{MCP}, \mathrm{Ca}\left(\mathrm{H}_{2} \mathrm{PO}_{4}\right)_{2}\right.$. $\left.\mathrm{H}_{2} \mathrm{O}\right)$ にアンモニア水を急速滴下する方法により, $\mathrm{Ca} / \mathrm{P}$ 原子 比1.25〜1.55の ACP を合成し，その熱的性質及び結晶化した リン酸カルシウムの形態及び組成により 3 種に大別した ${ }^{6)}$.こ の ACP は微細粒子で活性に富んでいるため8),15)，合成時に添 加物を加えることにより有機物との複合化や，イオン交換性な どが報告されている10),11),16)。更に， ACP を温度あるいは $\mathrm{pH}$ の異なる溶液中で結晶化させることによりリン酸一水素カルシ ウム二水和物 $\left(\mathrm{DCPD}, \mathrm{CaHPO}_{4} \cdot 2 \mathrm{H}_{2} \mathrm{O}\right)$, リン酸八カルシウム $\left(\mathrm{OCP}, \mathrm{Ca}_{8} \mathrm{H}_{2}\left(\mathrm{PO}_{4}\right)_{6} \cdot 5 \mathrm{H}_{2} \mathrm{O}\right)$ 及び $\mathrm{HAp}$ などを合成することが できる6),9),17)。この ACP は真空中で保存することにより長期 にわたり安定に保存できることから, 著者らはACP を出発原 料とした各種リン酸カルシウムの合成に注目している。しか し，これらの各種リン酸カルシウムはすべて室温以上での非晶 質リン酸カルシウムの結晶化であり，それよりも低温領域中で の結晶化についての報告は見られない.

そこで, 本研究では ACP を低温溶液中で結晶化させたとこ ろ, $\mathrm{ACP}$ を原料として用いたときにのみ生成する, リン酸力 ルシウム系新化合物 $\mathrm{Ca}_{3}\left(\mathrm{PO}_{4}\right)_{2} \cdot 8 \mathrm{H}_{2} \mathrm{O}$ を発見したので，その 生成条件とキャラクターについて以下報告する。

\section{2. 試料及び実験方法}

2.1 試料

$\mathrm{ACP}$ は湿式法により合成されるのが一般的である。本報告 では，幅広い範囲の $\mathrm{Ca} / \mathrm{P}$ 原子比1.25 1.55の ACP 在得万こ とができる $\mathrm{MCP}$ 溶液にアンモニア水を急速滴下する加水分解 法により $\mathrm{ACP}$ を合成した。このとき, 出発原料である $\mathrm{MCP}$, 滴下するアンモニア水は関東化学製特級試薬を, $\mathrm{ACP}$ の洗浄 及び乾燥に用いたアセトンは関東化学製工業用アセトン（純度 98\%）党用いた。な抢，リン酸カルシウム系新化合物の合成 に使用した溶液の $\mathrm{pH}$ の調整は, $1 \mathrm{~N} \mathrm{HNO}_{3}$ 及び $1 \mathrm{~N} \mathrm{KOH}$ を用 いた。これらはいずれも関東化学製特級試薬である。

\section{2 実験方法}

$\mathrm{MCP}$ の加水分解法は, 温度 $0^{\circ} \mathrm{C}$ の $0.005 \sim 0.07 \mathrm{~mol} \cdot \mathrm{dm}^{-3}$ $\mathrm{MCP}$ 溶液に, 所定濃度のアンモニア水を急速滴下することに より $\mathrm{ACP}$ 懸濁液が生成する。その後, この懸濁液を G5 ガラ スフィルターにより急速沪過し, 懸濁液と同じ $\mathrm{pH}$ のアンモニ ア水及びアセトンで十分に洗浄後, シリカゲルを通じた乾燥空 気で $30 \mathrm{~min}$ 乾燥を行い $\mathrm{ACP}$ を得た。この $\mathrm{ACP}$ は $\mathrm{Ca} / \mathrm{P}$ 原子 比の相違に応じて， L-ACP, M-ACP , H-ACP とに分類できる ことを著者らはすでに報告している6)。

リン酸カルシウム系新化合物の調製法については，上記の方 法により合成した $\mathrm{Ca} / \mathrm{P}$ 原子比 $1.25 \sim 1.55$ の $\mathrm{ACP}$ を, 温度 0 $20^{\circ} \mathrm{C}, \mathrm{pH} 2 \sim 12$ に調整した $100 \mathrm{~cm}^{3}$ の水溶液中で $0 \sim 240 \mathrm{~h}$ ，ス ターラーによりかくはん速度を $250 \mathrm{rpm}$ に調整した条件下で熟 成を行い, ACP の結晶化によってリン酸カルシウム水和物を 得た。この生成物は G5 ガラスフィルターで吸引沪過し, 純水 及びアセトンを用いて, 十分に洗浄後, ACP 々同様に, シリ カゲルを通じた乾燥空気中で $30 \mathrm{~min}$ 乾燥して試料とした。

また，得られた生成物のキャラクタリゼーションは，イオン クロマトグラフィー, フーリエ変換赤外分光光度計（FT- 
IR)，熱分析（TG-DTA），X線回折及び走査型電子顕微鏡 (SEM) 観察などにより行った.なお，晶系や格子定数などの 結晶学的データは理学電気製 X 線回折装置（RINT-2500）を 用いた粉末 X 線回折法により決定した。 また，このとさの測 定条件は電压 $50 \mathrm{kV}$, 電流 $300 \mathrm{~mA}, \mathrm{DS}^{\circ}, \mathrm{SS}^{\circ}, \mathrm{RS} 0.15^{\circ}$, ス

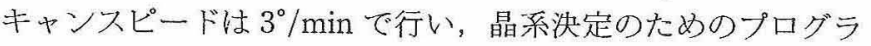
ムは RINT-2500のむのを用いた18).

\section{3. 实験結果及び考察}

\section{1 新祖の生成条件}

ACP を水中に浸漬させたときの結晶化についてはすでに報 告されて扔り，出発原料である $\mathrm{ACP}$ の $\mathrm{Ca} / \mathrm{P}$ 原子比にも上る が，一般に温度 $25 \sim 40^{\circ} \mathrm{C}, 40 \sim 60^{\circ} \mathrm{C}, 60 \sim 80^{\circ} \mathrm{C}$ ではそれぞれ DCPD, OCP, HAp となる ${ }^{97}$ 。図 1 は ACP $0^{\circ} \mathrm{C}$ 水中に浸漬 させたときの結晶化による新相の生成を示したもので少る。一 般的に ACP は低温になるほど結晶化時間は荤くなるが，溶液 が凍結する直前の温度 $0^{\circ} \mathrm{C}$ 付近では, 約 $6 \mathrm{~h}$ 後には結晶化が起 こり，2 $\theta=8.4^{\circ}$ 付近に回折ピークがわずかに見られるようにな る. 更に $120 \mathrm{~h}$ 経過すると, $2 \theta=8.4^{\circ}, 17.0^{\circ}, 34.4^{\circ}$ にそれぞれ 特徵的な回折ピークが確認できる。このX線回折結果から, ICDD 粉末データファイルを検索した結果，これまで既知であ るリン酸カルシウム系化合物のデータ々は一致せず，更に FT-IR, TG-DTA 及び化学分析などの結果も一致しないこと から，これらの未知回折ピークはリン酸カルシウム系化合物の 新相であると推察される。

$\mathrm{ACP}$ を温度 $0^{\circ} \mathrm{C}, \mathrm{pH} 10$ 溶液中で $24 \mathrm{~h}$ 熟成を行い, 生成し た新相のSEM 写真を図 2 に示す。新相の形状は粒径 $4 \sim 6$ $\mu \mathrm{m}$ 程度の板状結晶であり，新相の生成条件が相違しても形状 には変化が見られない。

新相の生成に及ほすす温度と $\mathrm{pH}$ の関係について示したのが 図 3 である。新相は低温，とくに温度 $0^{\circ} \mathrm{C}$ に捺いては $\mathrm{pH}$ に関 係なく生成する。しかし，温度が高くなると OCP が生成しは じめ新相との混合相となるが， $\mathrm{pH}$ の高い水溶液中では，単一 相の生成する温度範囲が高温度側をで桩大される傾向が見られ

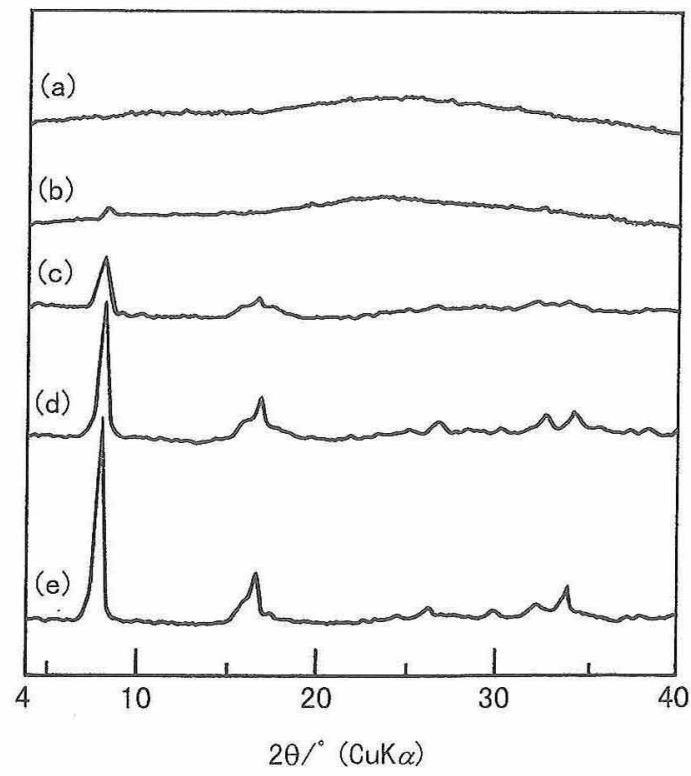

Fig. 1. Formation process of the new phase in solution.

Temperature: $0^{\circ} \mathrm{C}$, Initial $\mathrm{pH}: 10$, Stirring rate: $250 \mathrm{rpm}, \mathrm{Ca} / \mathrm{P}$ atomic rate of ACP: 1.44, Aging time (h), (a) 3, (b) 6, (c) 9, (d) 24 , (e) 120

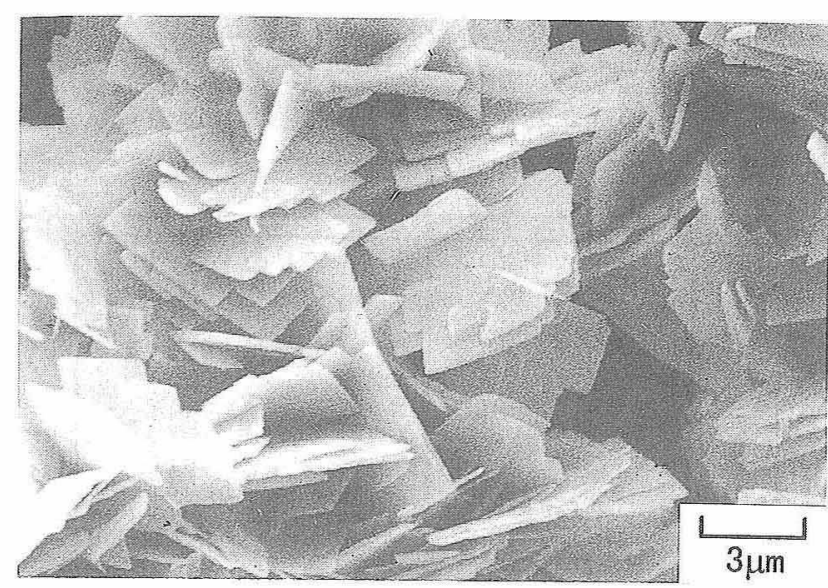

Fig. 2. Crystal shape of the new phase.

Temperature: $0{ }^{\circ} \mathrm{C}$, Initial $\mathrm{pH}$ : 10 , Stirring rate: $250 \mathrm{rpm}, \mathrm{Ca} / \mathrm{P}$ atomic ratio of $\mathrm{ACP}: 1.44$, Aging time: $24 \mathrm{~h}$.

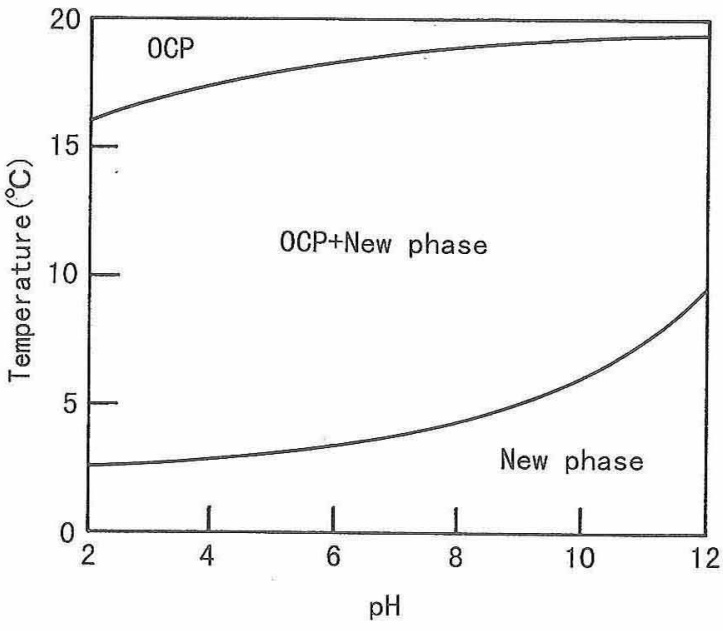

Fig. 3. Effect of temperature and $\mathrm{pH}$ on formation of the new phase.

Stirring rate: $250 \mathrm{rpm}, \mathrm{Ca} / \mathrm{P}$ atomic rate of $\mathrm{ACP}: 1.44$, Aging time: $24 h$.

た。

$\mathrm{ACP}$ は $\mathrm{Ca} / \mathrm{P}$ 原子比1.25〜1.55すでの幅広い範国の組成を 有するが，新相を生成させるためには，このことも考慮しなけ ればならない。そこで出発原料である $\mathrm{ACP} の \mathrm{Ca} / \mathrm{P}$ 原子比を 変化させたときの結晶化について示したのが図 4 である。著者 らは便宜上，これらをすでに述べたように 3 種に大別した6). この結果, $\mathrm{Ca} / \mathrm{P}$ 原子比 $1.44,1.50$ 及び1.55の高力ルシウム型 $\mathrm{H}-\mathrm{ACP}$ では新相の単一相のみが生成したが, 原子比 1.37 の $\mathrm{M}-\mathrm{ACP}$ では OCP との混合相，原子比 1.28 の-ACP では OCP 々DCPD 々の混合相と，それぞれ出発原料である $\mathrm{ACP}$ の $\mathrm{Ca} / \mathrm{P}$ 原子比に類似したリン酸力ルシウムへと結晶化した.

つぎに，新相の生成に及ぼすかくはん速度の影響について検 討を行ったのが図 5 である。かくはん速度が低下すると結晶性 は急激に低下する，また，かくはん物では新相しか生成しない が，末かくはん物では OCP の生成が見られるようになる。 こ れは，かくはんを行うことにより新相の生成速度が著しく促進 され， ACP が OCP の中間段階を経ずにすみやかに新相へと 結晶化するためと考えられる，また，かくはんを行和なけれ ば，まだ結晶化していない ACP が存在するためこれが OCP 
に結晶化し，混合相になるものと考えられる。

3.2 新相の性質

$\mathrm{Ca} / \mathrm{P}$ 原子比の異なる $\mathrm{ACP}$ を熟成させたときの $\mathrm{Ca} / \mathrm{P}$ 原子

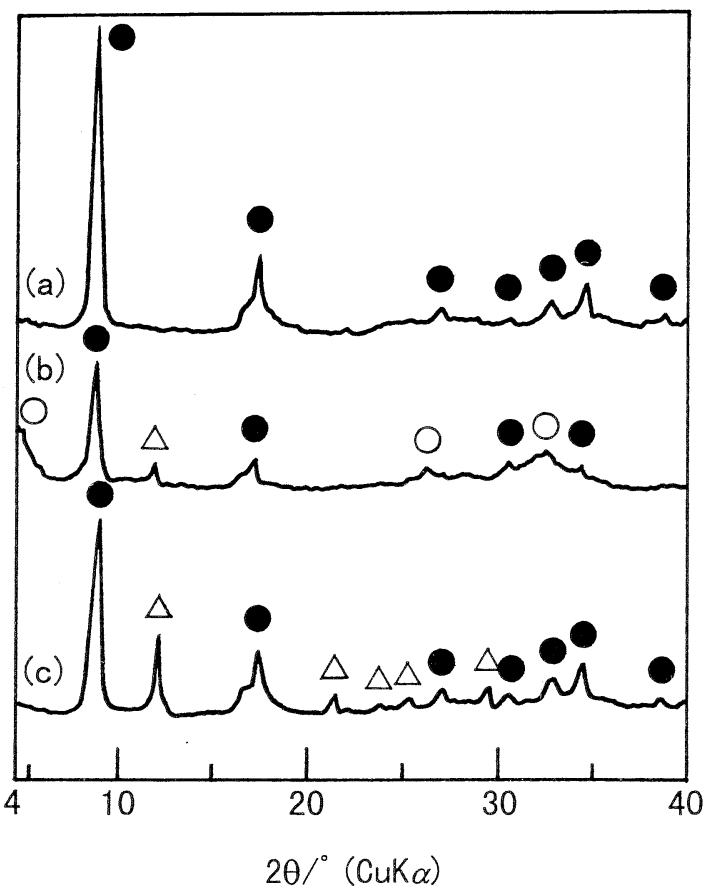

Fig. 4. Effect of $\mathrm{Ca} / \mathrm{P}$ atomic ratio of $\mathrm{ACP}$ on formation of the new phase.

Temperature: $0^{\circ} \mathrm{C}$, Intial $\mathrm{pH}: 10$, Stirring rate: $250 \mathrm{rpm}$, Aging time: $24 \mathrm{~h}, \mathrm{Ca} / \mathrm{P}$ atomic ratio: (a) 1.44 or 1.55 , (b) 1.38 , (c) 1.27 .

- New phase, $\bigcirc \mathrm{OCP}, \triangle \mathrm{DCPD}$.

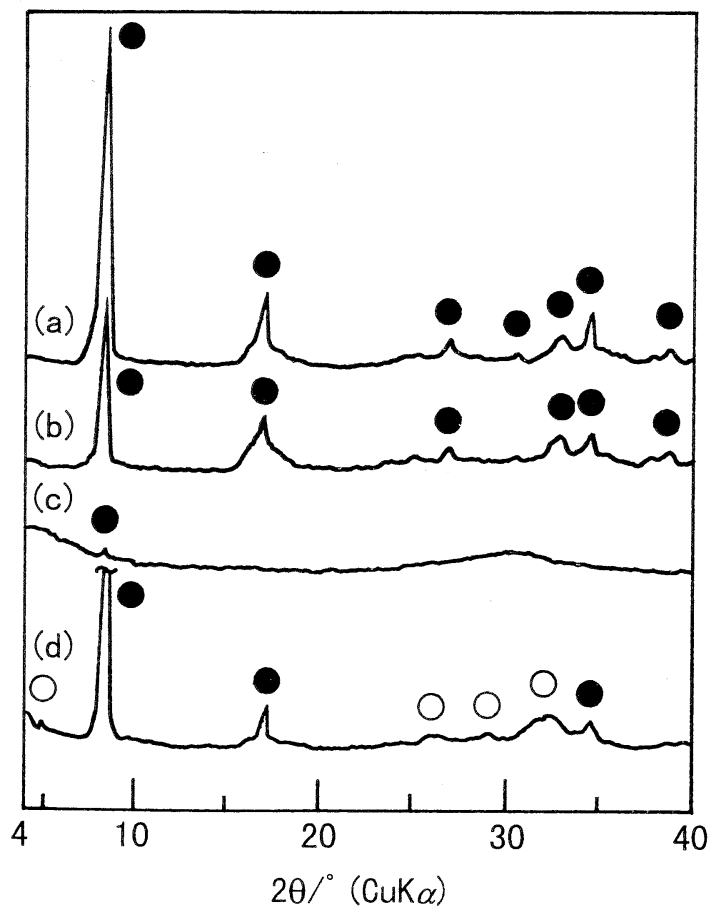

Fig. 5. Effect of stirring on formation of the new phase.

Temperature: $0^{\circ} \mathrm{C}$, Initial $\mathrm{pH}: 10, \mathrm{Ca} / \mathrm{P}$ atomic ratio of $\mathrm{ACP}: 1.44$, Stirring rate (rpm) and Aging time: (a) 250,24h, (b) 100,24h, (c) not stirring, $24 \mathrm{~h}$, (d) $250,120 \mathrm{~h}$.

New phase, $\bigcirc \mathrm{OCP}$.
比の経時変化をX線回折により追跡した結果を示したのが 図 6 である。出発原料である $\mathrm{ACP}$ の $\mathrm{Ca} / \mathrm{P}$ 原子比を 1.44 , 1.50, 1.55 と変化させて熟成を行ったが，いずれの場合でも約 $9 \sim 12 \mathrm{~h}$ 後に新相への結晶化が起こり, 最終的には $\mathrm{Ca} / \mathrm{P}$ 原子 比は 1.50 となり一定となった。したがって, 新相の $\mathrm{Ca} / \mathrm{P}$ 原子 比は1.50であることが確認できた。また，このときのリン酸の 形態は，イオンクロマトグラフィーによりすべて $\mathrm{PO}_{4}{ }^{3-}$ 基の 形態であることを確認した。

新相の赤外吸収スペクトルは，図 7 に示すように $673 \sim 798$ $\mathrm{cm}^{-1}$ に既存のリン酸力ルシウムには見られない特徵的な吸収 が見られた。この吸収帯は，400〜 500 ${ }^{\circ} \mathrm{C}$ 加熱することによ り消失することから，結晶水とリン酸基との結合に起因するも のと考えられる。 また，3100 3500 $\mathrm{cm}^{-1}$ 付近の OH 伸縮振 動に起因する吸収が 4 個に分裂して見られることから，4種の 結合形態の異なる水分子の存在が予想されるが，これはつぎに 示す熱分析の結果からも亭づけられる。 また，化学分析の結果 から，新相の組成は $\mathrm{CaO} 36.7 \%, \mathrm{P}_{2} \mathrm{O}_{5} 30.8 \%$, 強熱減量 $31.7 \%$ であった。以上, 新相の組成式は赤外吸収入ペクトル及び化学 分析の結果から, $\mathrm{Ca}_{3}\left(\mathrm{PO}_{4}\right)_{2} \cdot n \mathrm{H}_{2} \mathrm{O}$ で示されることが明らかと なった。

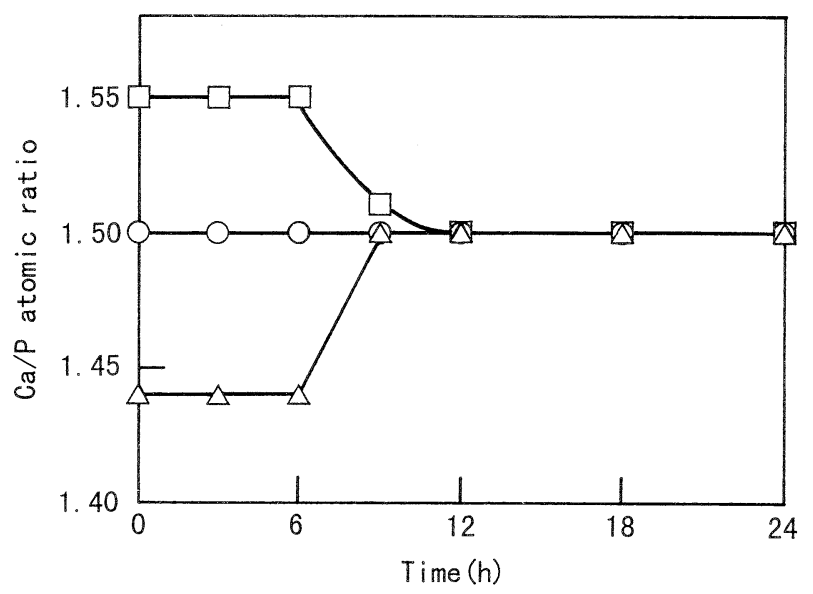

Fig. 6. Change in $\mathrm{Ca} / \mathrm{P}$ atomic ratio of product formed by crystallizing ACP.

Temperature: $0^{\circ} \mathrm{C}$, Initial $\mathrm{pH}: 10$, Stirring rate: $250 \mathrm{rpm}, \mathrm{Ca} / \mathrm{P}$ atomic ratio, $\square 1.55, \bigcirc 1.50, \triangle 1.44$.

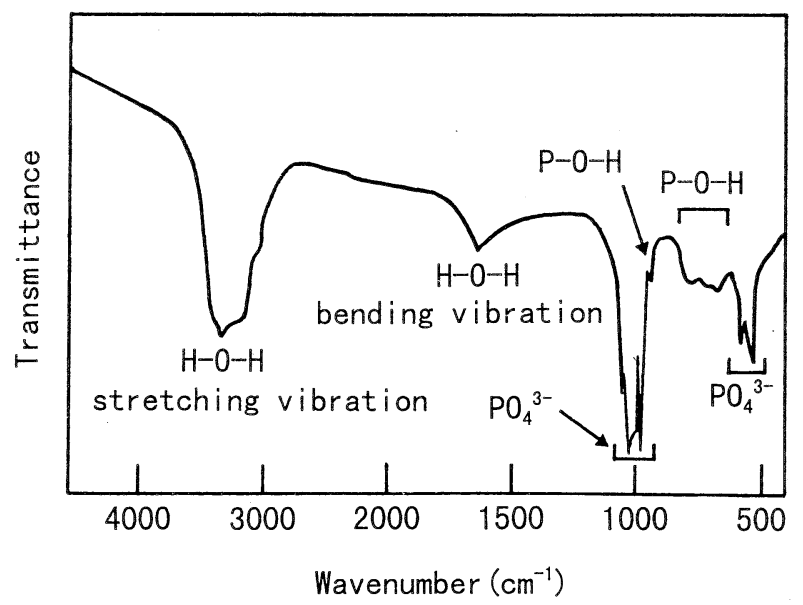

Fig. 7. Infrared spectrum of the new phase.

Temperature: $0^{\circ} \mathrm{C}$, Initial $\mathrm{pH}: 10$, Stirring rate: $250 \mathrm{rpm}, \mathrm{Ca} / \mathrm{P}$ atomic ratio of ACP: 1.44 . 

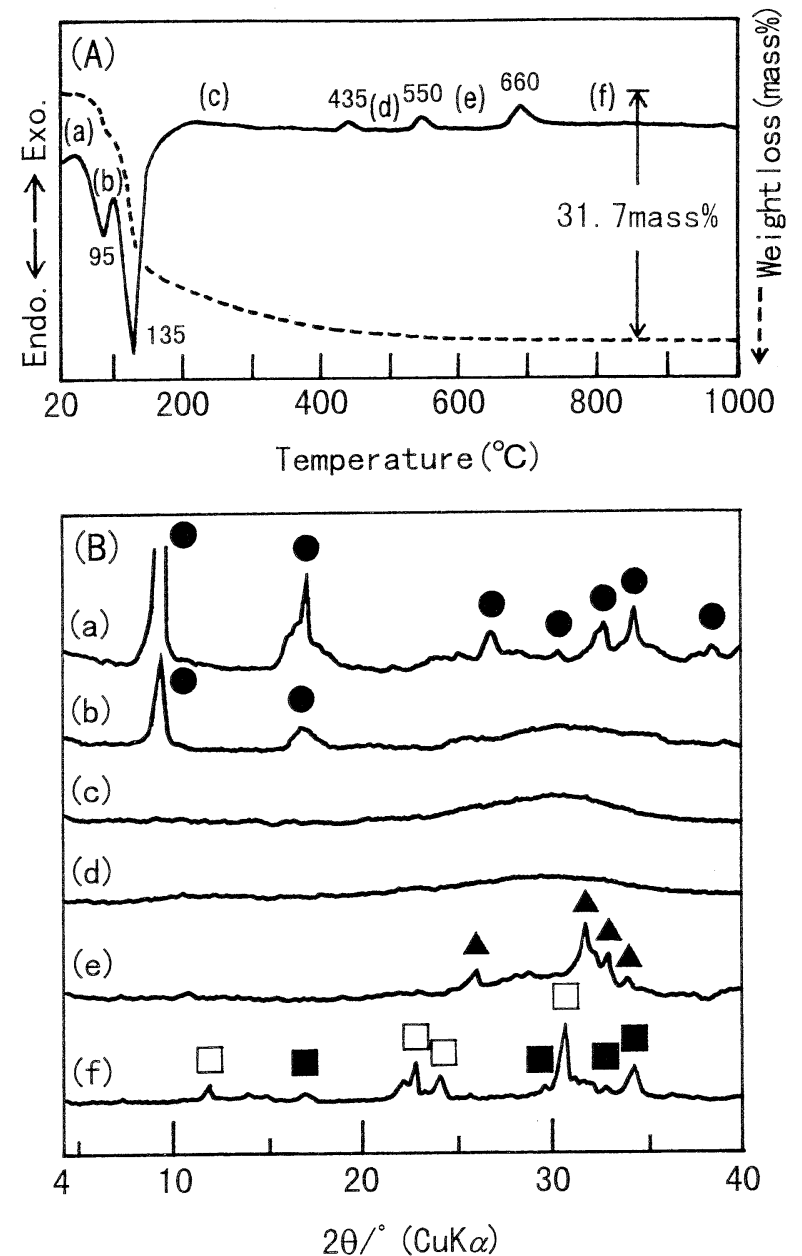

Fig. 8. Thermal decomposition of the new phase.

(A) TG-DTA curve, (B) X-ray diffraction pattern. Temperature ( $\left.{ }^{\circ} \mathrm{C}\right)$ : (a) 25, (b) 105 , (c) 250 , (d) 500 , (e) 600, (f) 800 .

New phase, $\boldsymbol{\Delta} \mathrm{HAp}, \square \alpha$-TCP, $\beta$-TCP.

つぎに新相の熱的性質の変化について検討を行ったのが図 8 である。新相は, $95^{\circ} \mathrm{C}$ と $135^{\circ} \mathrm{C}$ 付近に, 結晶水の脱水による 2 段階の吸熱ピークが見られ，これにともないX 線回折強度は 低下し, $200^{\circ} \mathrm{C}$ 付近では非晶質となった。 その後, $550^{\circ} \mathrm{C}$ 付近 で $\mathrm{HAp}$ の生成が見られ，最終的には $660^{\circ} \mathrm{C}$ 付近で $\alpha^{-1}$ リン酸三 カルシウムと $\beta$ リン酸三カルシウムとの混合相へと変化する. なお，このときの HAp の形状は，新相の形状を保持したまま の大きな板状結晶であった。また新相の脱水総減量は約 31.7 mass\%であることから，これより新相の構造水量を算出する 之8 分子であった。市た, 化学分析の結果から, $\mathrm{P}_{2} \mathrm{O}_{7}{ }^{4-}$, $\mathrm{NO}_{3}$-及び $\mathrm{K}^{+}$などの不純物は確認できなかった。したがっ て, 新相の組成式は $\mathrm{Ca}_{3}\left(\mathrm{PO}_{4}\right)_{2} \cdot 8 \mathrm{H}_{2} \mathrm{O}$ で示されるリン酸カル シウム八水和物であることが確認できた。
Table 1. Crystallographic Data for $\mathrm{Ca}_{3}\left(\mathrm{PO}_{4}\right)_{2} \cdot 8 \mathrm{H}_{2} \mathrm{O}$ Crystal System: Monoclinic

Lattice constant: $a=1.312 \mathrm{~nm}, \quad b=1.111 \mathrm{~nm}, \quad c=1.264 \mathrm{~nm}$, $\beta=109.0^{\circ}$

\begin{tabular}{|c|c|c|c|c|c|c|c|c|c|c|c|}
\hline$d_{0}$ & $d_{c}$ & $1 / I_{0}$ & $h$ & $k$ & 1 & $d_{0}$ & $d_{c}$ & $1 / I_{0}$ & $h$ & $k$ & 1 \\
\hline 10.52 & 10.48 & 100 & $\bar{T}$ & 0 & 1 & 2.773 & 2.782 & 10 & $\overline{4}$ & 2 & 2 \\
\hline \multirow[t]{2}{*}{5.555} & 5. 564 & 9 & $\overline{2}$ & 1 & 1 & & 2. 782 & & $T$ & 3 & 3 \\
\hline & 5. 555 & & 0 & 2 & 0 & & 2.778 & & 0 & 4 & 0 \\
\hline 5.460 & 5.437 & 10 & $T$ & 1 & 2 & & 2. 760 & & 3 & 3 & 0 \\
\hline 5. 401 & 5.418 & 11 & 2 & 1 & 0 & 2.734 & 2.742 & 20 & $\underline{3}$ & 3 & 2 \\
\hline \multirow[t]{2}{*}{ 5. 239} & 5.263 & 33 & 0 & 1 & 2 & & 2. 738 & & $\overline{1}$ & 2 & 4 \\
\hline & 5. 239 & & $\overline{2}$ & 0 & 2 & 2. 613 & 2. 625 & 20 & 3 & 2 & 2 \\
\hline \multirow[t]{2}{*}{5.038} & 5. 071 & 13 & 1 & 2 & 0 & & 2. 619 & & $\frac{\overline{4}}{4}$ & 0 & 4 \\
\hline & 5.038 & & 0 & 2 & 1 & & 2. 611 & & $\overline{4}$ & 2 & 3 \\
\hline 4. 935 & 4. 908 & 6 & 1 & 2 & 1 & & 2. 605 & & $\frac{1}{5}$ & 0 & 1 \\
\hline 4. 734 & 4. 738 & 3 & $\overline{2}$ & 1 & 2 & & 2. 604 & & 1 & 4 & 1 \\
\hline \multirow[t]{2}{*}{ 4. 471} & 4. 460 & 2 & 1 & 2 & 1 & & 2.602 & & 2 & 2 & 3 \\
\hline & 4. 480 & & 2 & 1 & 1 & 2. 567 & 2. 569 & 8 & 3 & 3 & 1 \\
\hline \multirow[t]{2}{*}{ 4. 410} & 4.413 & 2 & 1 & 1 & 2 & 2. 550 & 2.550 & 8 & $\underline{2}$ & 4 & 1 \\
\hline & 4. 374 & & $\overline{3}$ & 0 & 1 & & 2. 549 & & $\overline{4}$ & 1 & 4 \\
\hline 4. 115 & 4. 139 & 4 & 2 & 2 & 0 & & 2.544 & & $\overline{5}$ & 1 & 2 \\
\hline \multirow[t]{2}{*}{ 4. 044} & 4.070 & 3 & $\overline{3}$ & 1 & 1 & & 2. 541 & & $\overline{3}$ & 3 & 3 \\
\hline & 4. 069 & & 0 & 2 & 2 & 2.490 & 2. 494 & 6 & 4 & 2 & 1 \\
\hline 3. 948 & 3.939 & 2 & $T$ & 1 & 3 & & 2. 493 & & 3 & 0 & 3 \\
\hline \multirow[t]{2}{*}{ 3. 815} & 3. 828 & 3 & $\overline{3}$ & 1 & 2 & 2. 464 & 2. 460 & 6 & $\overline{2}$ & 1 & 5 \\
\hline & 3. 811 & & $\overline{2}$ & 2 & 2 & 2. 446 & 2. 454 & 6 & $\underline{2}$ & 4 & 2 \\
\hline \multirow[t]{2}{*}{3.770} & 3. 759 & 5 & $\overline{2}$ & 1 & 3 & & 2.453 & & $\frac{\pi}{4}$ & 3 & 1 \\
\hline & 3. 750 & & 0 & 1 & 3 & & 2. 448 & & 4 & 0 & 2 \\
\hline \multirow[t]{2}{*}{ 3. 722} & 3.740 & 5 & 2 & 0 & 2 & & 2. 442 & & $\frac{1}{5}$ & 1 & 3 \\
\hline & 3. 704 & & 0 & 3 & 0 & & 2. 442 & & $\frac{\pi}{1}$ & 1 & 5 \\
\hline 3.635 & 3. 636 & 5 & 1 & 2 & 2 & & 2. 442 & & $\frac{1}{3}$ & 0 & 5 \\
\hline \multirow[t]{4}{*}{ 3. 551} & 3. 567 & 8 & 3 & 0 & 1 & & 2.437 & & 1 & 2 & 4 \\
\hline & 3. 549 & & 1 & 3 & 0 & 2. 406 & 2. 416 & 7 & 2 & 4 & 1 \\
\hline & 3.545 & & 2 & 1 & 2 & & 2. 405 & & 1 & 4 & 2 \\
\hline & 3. 538 & & 0 & 3 & 1 & & 2. 404 & & 2 & 0 & 4 \\
\hline \multirow[t]{2}{*}{ 3. 515} & 3.493 & 5 & $\overline{3}$ & 0 & 3 & & 2. 398 & & $\frac{5}{1}$ & 3 & 4 \\
\hline & 3. 492 & & $T$ & 3 & 1 & 2. 386 & 2. 390 & 7 & 4 & 1 & 2 \\
\hline 3.393 & 3. 397 & 5 & 3 & 1 & 1 & & 2. 385 & & $\frac{1}{3}$ & 1 & 5 \\
\hline 3. 356 & 3. 357 & 10 & $T$ & 2 & 3 & & 2. 385 & & $\frac{\pi}{2}$ & 3 & 4 \\
\hline \multirow{4}{*}{3.329} & 3. 332 & 14 & $\overline{3}$ & 1 & 3 & & 2. 378 & & 4 & 3 & 0 \\
\hline & 3. 320 & & 1 & 1 & 3 & 2. 338 & 2. 345 & 7 & $\overline{3}$ & 4 & 1 \\
\hline & 3. 319 & & 1 & 3 & 1 & & 2. 337 & & $\underline{0}$ & 1 & 5 \\
\hline & 3. 318 & & 3 & 2 & 0 & 2. 290 & 2. 297 & 6 & $\underline{2}$ & 2 & 5 \\
\hline \multirow[t]{2}{*}{3.240} & 3. 242 & 8 & $\frac{\pi}{2}$ & 2 & 3 & & 2. 296 & & $\overline{3}$ & 4 & 2 \\
\hline & 3.238 & & 0 & 2 & 3 & & 2. 290 & & $\overline{3}$ & 3 & 4 \\
\hline 3.170 & 3.184 & 7 & $\frac{\pi}{1}$ & 3 & 2 & & 2.287 & & 5 & 0 & 1 \\
\hline & 3. 180 & & 2 & 3 & 0 & & 2. 282 & & $\overline{5}$ & 2 & 3 \\
\hline 3.151 & 3. 148 & 7 & 0 & 3 & 2 & & 2. 282 & & $T$ & 2 & 5 \\
\hline & 3. 140 & & $\overline{4}$ & 1 & 1 & & 2. 281 & & $\frac{\pi}{2}$ & 4 & 3 \\
\hline 3. 100 & 3.117 & 5 & $\overline{2}$ & 0 & 4 & 2. 267 & 2. 275 & 7 & 3 & 2 & 3 \\
\hline & 3. 103 & & 4 & 0 & 0 & & 2. 266 & & 5 & 2 & 0 \\
\hline & 3. 102 & & 2 & 2 & 2 & & 2. 266 & & $\overline{5}$ & 1 & 4 \\
\hline & 3. 087 & & $\frac{2}{4}$ & 1 & 2 & 2. 236 & 2. 240 & 8 & 5 & 1 & 1 \\
\hline 2. 992 & 3. 002 & 5 & 3 & 2 & 1 & & 2. 240 & & $\overline{4}$ & 1 & 5 \\
\hline & 3.001 & & $\frac{\pi}{2}$ & 1 & 4 & & 2. 240 & & 4 & 2 & 2 \\
\hline & 2. 989 & & 4 & 1 & 0 & & 2. 236 & & $\overline{3}$ & 2 & 5 \\
\hline & 2. 988 & & 0 & 0 & 4 & & 2. 230 & & 2 & 4 & 2 \\
\hline 2. 946 & 2. 957 & 5 & $\overline{3}$ & 2 & 3 & & 2. 229 & & 4 & 3 & 1 \\
\hline & 2. 954 & & 2 & 3 & 1 & 2. 205 & 2. 206 & 16 & 2 & 2 & 4 \\
\hline & 2. 948 & & 1 & 2 & 3 & 2. 195 & 2. 196 & 6 & 0 & 2 & 5 \\
\hline 2. 936 & 2. 934 & 10 & 1 & 3 & 2 & & 2. 192 & & 3 & 4 & 1 \\
\hline 2. 886 & 2. 886 & 5 & 0 & 1 & 4 & & 2. 188 & & 1 & 3 & 4 \\
\hline & 2. 877 & & 3 & 1 & 2 & & 2. 187 & & 1 & 5 & 0 \\
\hline & & & & & & & 2. 187 & & $\overline{6}$ & 0 & 2 \\
\hline
\end{tabular}

更に，新相の熱的性質の変化は，脱水にともなって(1)式 〜 (5)式で示される.

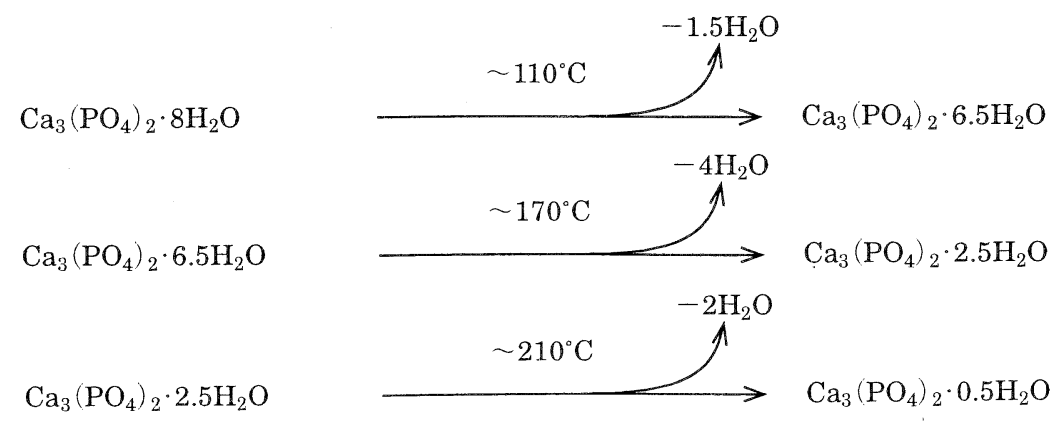




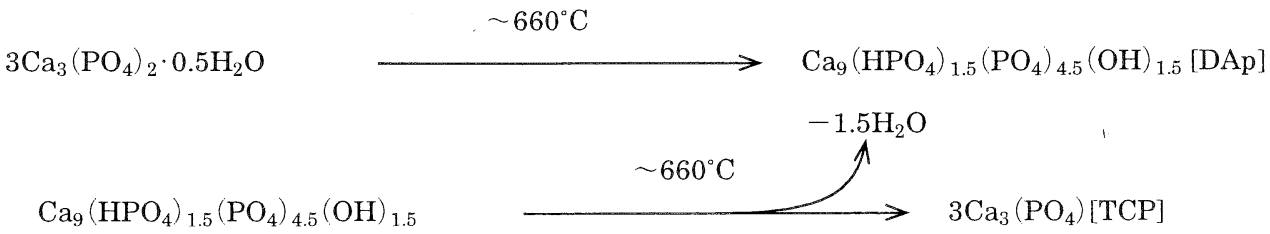

$\mathrm{Ca}_{9}\left(\mathrm{HPO}_{4}\right)_{1.5}\left(\mathrm{PO}_{4}\right)_{4.5}(\mathrm{OH})_{1.5}$

また，新相の X 線回折図形はピーク数も多く，ブロードな ピークも見られるため，その正確な構造解析は困難であるが， 新相の粉末 X 線回折データをもとに結晶学的データを算出し たものが表 1 である。 その結果, 新相の晶系は単斜晶系であり, $a=1.312 \mathrm{~nm}, b=1.111 \mathrm{~nm}, c=1.264 \mathrm{~nm}, \beta=109.0^{\circ}$ であった. しかし，著者らは現在新相の単結晶の合成について検討を行っ ており，最終的にはこれにより決定したいと考えている。

また, 新相に組成の類似した 8 水和物を持つグループ $\left(\mathrm{A}_{3}\left(\mathrm{XO}_{4}\right)_{2} \cdot 8 \mathrm{H}_{2} \mathrm{O}: \mathrm{A}=\mathrm{Mg}, \mathrm{Fe}, \mathrm{Co}, \mathrm{Ni}, \mathrm{Zn}: \mathrm{X}=\mathrm{P}, \mathrm{As}\right)$ の存 在が知られており19) 24), とくに，A=Coであるリン酸コバル 卜八水和物 $\left(\mathrm{Co}_{3}\left(\mathrm{PO}_{4}\right)_{2} \cdot 8 \mathrm{H}_{2} \mathrm{O}\right)$ は, 形状及び熱的挙動などい ろいろな点で類似している。

$\mathrm{Ca}_{3}\left(\mathrm{PO}_{4}\right)_{2} \cdot 8 \mathrm{H}_{2} \mathrm{O}$ で示される新相の大気中での安定性につい て検討を行ったのが図 9 である。新相は180日を経過しても安 定であるが，270日経過すると完全にHApに変化する。この HAp の形状はもとの新相に比へててずかに小さな板状結晶で 岁った。このことから，新相は時間の経過にともない結晶水が 脱離し板状結晶が崩壊していくものと考えられる。また，大気 中で安定である新相は，水溶液中に扔いても安定であり，上く に温度 $20^{\circ} \mathrm{C}$ においては $120 \mathrm{~h}$ 後まで安定に存在した。

\section{4. むすび}

リン酸カルシウムには多くの化合物が存在するが，とくに $\mathrm{ACP}$ は微細で活性に富んだ非晶質物質で, これを出発原料と して, 必要に応じて多種類のリン酸カルシウム系化合物の単一

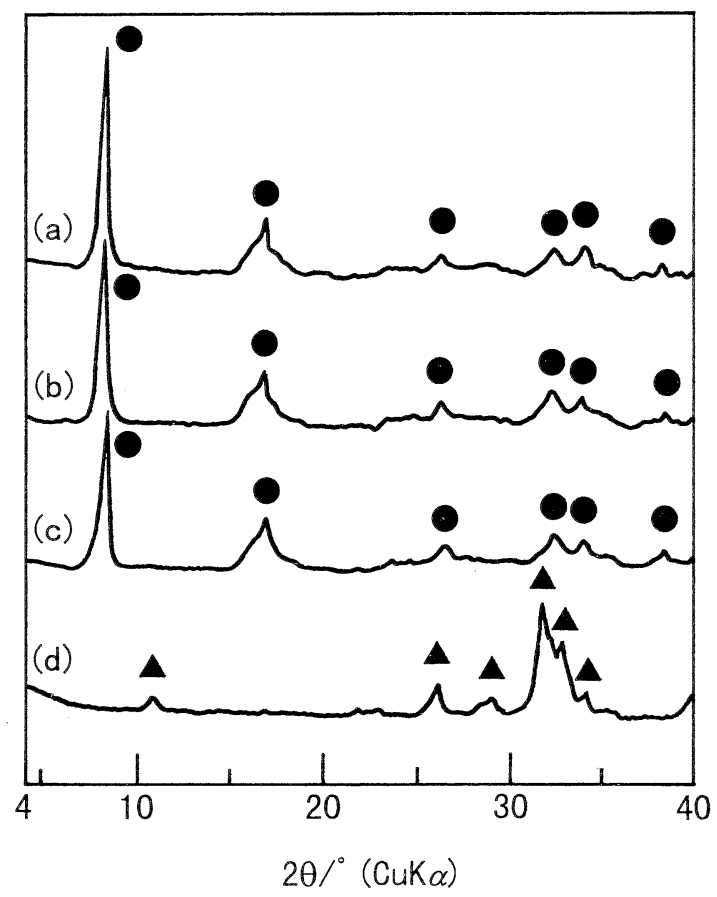

Fig. 9. Stability of the new phase in atomosphere. Time (d): (a) 0, (b) 90, (c) 180, (d) 270.

New phase, $\boldsymbol{\Delta}$ HAp.
相へと容易に結晶化させることが可能である。本研究では， ACP の低温領域での結晶化について検討を行ったところ, 組 成 $\mathrm{Ca}_{3}\left(\mathrm{PO}_{4}\right)_{2} \cdot 8 \mathrm{H}_{2} \mathrm{O}$ で表される新相を発見した。この新相の 結晶学データは, 単斜晶系, $a=1.312 \mathrm{~nm}, b=1.111 \mathrm{~nm}, c=$ $1.264 \mathrm{~nm}, \beta=109.0^{\circ}$ であり, 形状は板状であった。

なた， $\mathrm{ACP}$ は $500^{\circ} \mathrm{C}$ 加熱することによりリン酸三カルシウ ム (TCP) に類似した組成の非晶質リン酸三カルシウム (ATCP) となり，これを有機酸と混練することにより直接硬 化体を作製できることを著者らは報告している年。この ATCP は微細なため水/固体比を小さくすることはできない。 しかし，新相を $500^{\circ} \mathrm{C} に$ 加熱することにより得られた ATCP は新相の形状を保持したますの大きな板状であるため, 水/固 体比を小さくすることが可能であり，この新相を用いることに より高強度生体材料としての利用も期待できる。

\section{文献}

1）安江 任, 間宮 晶, 高橋裕八, 築坂亮吾, 荒井康夫, 日化, 1107-13 (1984)。

2) 安江任, 間宮 晶, 福島貴, 荒井康夫, 石膏と石灰, No. 198, 245-52 (1985).

3）安江 任, 瀬高俊哉, 梅澤英之, 荒井康夫, 石膏と石灰, No. 216, 295-304 (1988).

4）安江 任, 小嶋芳行, 荒井康夫, セラミックス論文誌, 98, 483-89 (1990).

5) 安江 任, 榊田順子, 吉山明裕, 荒井康夫, 石膏と石灰, No. 229, 387-95 (1990).

6) T. Yasue, A. Yoshiyama and Y. Arai, Phos. Res. Bull., 1, 2730 (1991).

7) T. Yasue, Y. Kojima, A. Yoshiyama and Y. Arai, Phos. Sulf. Silicon, 77, 290 (1993)

8）安江 任, 荒井康夫, 石膏と石灰, No. 243, 42-50 (1993).

9) Y. Kojima, K. Sakama, T. Toyama, T. Yasue and Y. Arai, Phos. Res. Bull., 4, 47-52 (1994).

10）安江 任, 增田賢太, 小嶋芳行, 荒井康夫, J. Ceram. Soc. Japan, 102, 1122-27 (1994)

11) Y. Kojima, Y. Yamamoto, T. Yasue and Y. Arai, Phos. Res. Bull., 5, 59-64 (1995).

12）小嶋芳行, 市村高央, 安江 任, 荒井康夫, 無機マテリアル, 2, 181-86 (1995).

13）小嶋芳行, 遠藤典秀, 安江 任, 荒井康夫, J. Ceram. Soc. Japan, 103, 1282-88 (1995).

14）安江 任, 小嶋芳行, 遠山岳史, 荒井康夫, 無機マテリアル 学会第91回学術講演会要旨集 (1995) pp. 10-11.

15) F. Betts, N. C. Blumenthal and A. S. Posner, J. Cryst. Growth, 53, 63-73 (1981).

16）嶋林三郎, 石膏と石灰, No. 243, 99-107 (1993).

17）梅垣高士，柴 繁伸，金澤孝文，石膏と石灰，No. 210, 28286 (1987).

18）高木義人，谷口友彦，堀 幸一，J. Ceram. Soc.Japan, 101, 373-76 (1993).

19) T. Kanazawa, T. Umegaki and M. Shimizu, Bull. Chem. Soc. Jpn., 52, 3713-17 (1979).

20) T. F. W. Barth, Am. Mineralogist, 22, 325-39 (1937).

21）橋本和明, 戸田善朝, 橋本甲四郎, 荒井康夫, 石膏と石灰, No. 238, 177-84 (1992).

22）戸田善朝，橋本和明，橋本甲四郎，荒井康夫，石膏と石灰， No. 206, 10-22 (1987).

23) T. Yamaguti, Proc. Phys. Math. Soc. Jpn., 18, 372-79 (1936).

24) H. Mori and T. Ito, Acta Cryst., 3, 1-6 (1950). 